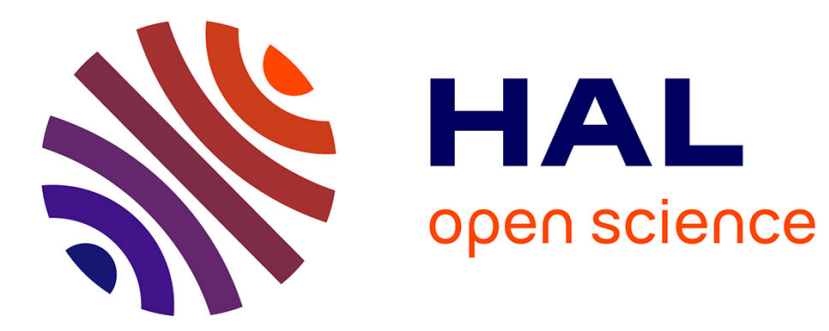

\title{
Functional characterization of Penicillium occitanis Pol6 and Penicillium funiculosum GH11 xylanases
}

Dorra Driss, Jean-Guy Berrin, Nathalie Juge, Fatma Bhiri, Raoudha Ghorbel, Semia Ellouz Chaabouni

\section{- To cite this version:}

Dorra Driss, Jean-Guy Berrin, Nathalie Juge, Fatma Bhiri, Raoudha Ghorbel, et al.. Functional characterization of Penicillium occitanis Pol6 and Penicillium funiculosum GH11 xylanases. Protein Expression and Purification, 2013, 90 (2), pp.195-201. 10.1016/j.pep.2013.06.007 . hal-01268059

\section{HAL Id: hal-01268059 \\ https://hal.science/hal-01268059}

Submitted on 29 May 2020

HAL is a multi-disciplinary open access archive for the deposit and dissemination of scientific research documents, whether they are published or not. The documents may come from teaching and research institutions in France or abroad, or from public or private research centers.
L'archive ouverte pluridisciplinaire HAL, est destinée au dépôt et à la diffusion de documents scientifiques de niveau recherche, publiés ou non, émanant des établissements d'enseignement et de recherche français ou étrangers, des laboratoires publics ou privés. 
Version définitive du manuscrit publiée dans / Final version of the manuscript published in:

Protein Expression and Purification (2013), Vol. 90, №.2, p. 195-201, DOI: 10.1016/j.pep.2013.06.007

Journal homepage: http://www.elsevier.com/locate/yprep

\title{
Functional characterization of Penicillium occitanis Pol6 and Penicillium funiculosum GH11 xylanases
}

\author{
Dorra Driss $^{\text {a,* }}$, Jean Guy Berrin ${ }^{\text {b,c }}$, Nathalie Juge ${ }^{\mathrm{d}}$, Fatma Bhiri ${ }^{\mathrm{a}, \mathrm{e}}$, Raoudha Ghorbel ${ }^{\mathrm{a}, \mathrm{e}}$, \\ Semia Ellouz Chaabouni ${ }^{\mathrm{a}, \mathrm{e}}$ \\ a Unité Enzymes et Bioconversion, Ecole Nationale d'Ingénieurs de Sfax, Université de Sfax, route de Soukra, 3038 Sfax, Tunisia \\ b INRA, UMR1163 Biotechnologie des Champignons Filamenteux, 13009 Marseille, France \\ 'Aix Marseille Université, Polytech' Marseille, 13009 Marseille, France \\ ${ }^{\mathrm{d}}$ Institute of Food Research, The Gut Health and Food Safety Institute Strategic Programme, Norwich Research Park, Norwich NR4 7UA, UK \\ e Unité de service commun bioréacteur couplé à un ultrafiltre, Ecole Nationale d'Ingénieurs de Sfax, Université de Sfax, route de Soukra, 3038 Sfax, Tunisia
}

Keywords:

Penicillium occitanis Pol6

Penicillium funiculosum

Thumb

Xylanase

Glycoside hydrolase 11

Pichia pastoris expression

Xylan

\begin{abstract}
A B S T R A C T
Xylanases are hemicellulolytic enzymes, which are responsible for the degradation of heteroxylans constituting the lignocellulosic plant cell wall. Xylanases from the GH11 family are considered as true xylanases because of their high substrate specificity. In order to study in depth a crucial difference in the thumb region between two closely related xylanases from Penicillium in terms of kinetic parameters and inhibition sensitivity, the GH11 xylanases from Penicillium occitanis Pol6 (PoXyn3) and from Penicillium funiculosum (PfXynC) were heterologously expressed in Pichia pastoris. The PoXyn3 and PfXynC cDNAs encoding mature xylanases were cloned into $\mathrm{pGAPZ} \alpha \mathrm{A}$ vectors and integrated into the genome of $P$. pastoris X-33 under the control of the glyceraldehyde 3-phosphate dehydrogenase constitutive promoter. PfXynC was expressed as a His-tagged recombinant protein and purified from the supernatant homogeneity by a one-step purification protocol using immobilized metal affinity chromatography. The recombinant PoXyn3 was purified using a single anion-exchange chromatography. The purified recombinant enzymes were optimally active at $45^{\circ} \mathrm{C}$ and pH 4.0 for PoXyn 3 and $40{ }^{\circ} \mathrm{C}$ and $\mathrm{pH} 3.0$ for PfXynC. The measured kinetic parameters $\left(\mathrm{k}_{\mathrm{cat}}\right.$ and $V_{\max }$ ) showed that PfXynC was five times more active than PoXyn3 irrespective of the substrate whereas the apparent affinity $\left(K_{\mathrm{m}}\right)$ was similar. The recombinant enzymes showed distinct sensitivity to the Triticum aestivum xylanase inhibitor TAXI-I.
\end{abstract}

\section{Introduction}

Enzymatic hydrolysis of the plant cell wall release small carbohydrates that are utilized as an energy and carbon source by a range of organisms. This degradative process is of fundamental biological and industrial importance. Endo-(1,4)- $\beta$-xylanases (xylanases; EC 3.2.1.8) depolymerize the xylan backbone, a significant component of the plant cell wall, by cleaving the $\beta-(1,4)$ glycosidic bonds between D-xylose residues in the main chain to produceshort xylo-oligosaccharides [1]. Based on amino acid sequence similarities, xylanases are mainly classified into families GH10 and GH11 of glycoside hydrolases [2]. The two families have different molecular structures, molecular weights, and catalytic properties. Family GH10 generally consists of higher molecular weight proteins $(>30 \mathrm{kDa})$ with a $(\beta / \alpha)_{8}$ barrel structure, whereas family GH11 consists of lower molecular weight proteins (20-30 kDa) with a $\beta$-jelly-roll fold [3]. Enzymes with xylanolytic

\footnotetext{
* Corresponding author.

E-mail address: dorra_driss@yahoo.fr (D. Driss).
}

activities are also found in GH families GH5, GH8 and GH43 [4], but only GH11 family is monospecific, consisting solely of "true xylanases" exclusively active on xylan. The three-dimensional structure of GH11 xylanases has been described as a "partly closed right hand". This hand contains a thumb-like structure that connects the B7 and B8 $\beta$-strands, which is the most mobile region of the xylanase family 11 [7]. The movement of the loop affects the movement of the connecting strands and could be essential for the function of the enzyme. The thumb has also been identified as the target for some plant proteinaceous inhibitors [7-8]. Xylanases have been studied for their role in several industrial food processes, mainly in baking, wheat processing, and as supplements in animal feed production [3]. They are routinely used as bread-improvers, but the observed effects on bread volume, crumb texture, and flavour vary depending on the xylanase tested [5]. These differences could be due to the variability in xylanase specificity towards arabinoxylan but also to the presence of xylanase protein inhibitors in cereals [6]. To date, two main types of xylanase inhibitors with different structures and specificities have been described [6]. 
Version définitive du manuscrit publiée dans / Final version of the manuscript published in:

Protein Expression and Purification (2013), Vol. 90, №.2, p. 195-201, DOI: 10.1016/j.pep.2013.06.007

Journal homepage: http://www.elsevier.com/locate/yprep

196

The xylanase inhibitor protein (XIP)-type inhibitors can inhibit both GH10 and GH11 xylanases, whereas the Triticum aestivum xylanase inhibitor (TAXI)-type inhibitors are active against bacterial and fungal GH11 xylanases, but not against GH10 xylanases [9].

The methylotrophic yeast Pichia pastoris is a host system, which has been widely used in both academic and industrial laboratories for the production of a variety of heterologous proteins [10]. This system has many of the advantages of eukaryotic expression, such as the ability to carry out proteolytic processing, folding, disulphide bond formation, and glycosylation. A wide variety of proteins have been produced successfully using the tightly controlled methanolinducible alcohol oxidase 1 (AOX1) promoter, including the classical human pancreatic lipase [11]. Another Pichia expression systems based on the strong constitutive promoter of $P$. pastoris glyceraldehyde-3-phosphate dehydrogenase gene (GAP) have recently become available [12]. The GAP promoter is a convenient alternative to the inducible AOX1 promoter for the heterologous expression of genes giving products which are not toxic to $P$. pastoris, or when the use of methanol, a highly toxic solvent, has to be ruled out.

Penicillium fungi are primarily saprophytic in nature, and numerous species have been exploited in commercial food production (e.g., cheeses) and for the antibiotic penicillin. They have also been used for the production of xylanolytic enzymes [13]. The Penicillium occitanis Pol6 mutant secretes two xylanases termed PoXyn2 and PoXyn $3^{1}$, which were purified from culture supernatant and characterized in terms of biochemical properties $[14,15]$. Recently, PoXyn2 was successfully expressed in the methylotrophic yeast $P$. pastoris X-33 [16]. The PoXyn3 belongs to the GH11 family and is an extracellular, acidophilic xylanase with an unusual naturally deleted portion in the thumb, which was revealed by sequence analysis and modeling of the 3D structure (Fig. 1) [14]. PoXyn3 is closely related to the native Penicillium funiculosum xylanase C (PfXynC) with a more conventional thumb that was previously characterized notably with respect to its inhibition by XIP and TAXI [17]. In the present study, we report the expression and purification of Penicillium xylanases, PoXyn3 and PfXynC, in P. pastoris and the biochemical and enzymatic characterization of both recombinant enzymes in terms of kinetics towards arabinoxylan and inhibition sensitivity to TAXI-I.

\section{Materials and methods}

Strains, plasmids, culturing conditions

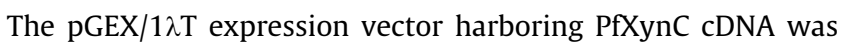
from [18] and the PoXyn3 cDNA cloned in the pGEMT-easy vector from [14].

The $P$. pastoris host strain $\mathrm{X}-33$ and $P$. pastoris transfer vector pGAPZ $\alpha A$ were from Invitrogen (San Diego, CA). P. pastoris liquid cell cultures were grown in buffered YPD medium containing $10 \mathrm{~g}$ yeast extract, $20 \mathrm{~g}$ Bacto-peptone, $20 \mathrm{~g}$ D-glucose, and $10 \mathrm{mM}$ sodium phosphate buffer with the $\mathrm{pH}$ initially adjusted to 6.8 . The YPDS medium used for recombinant yeasts culture was YPD medium to which $18.2 \mathrm{~g}$ sorbitol per liter was added. To prepare plates for solid cell cultures, $2 \%$ agar (w/v) was added to the YPD medium.

All cloning steps were performed in Escherichia coli, DH5 $\alpha$ cultured in low salt Luria-Bertani medium in the presence of $25 \mu \mathrm{g} /$ $\mathrm{ml}$ Zeocin (Invitrogen).

\section{Cloning of PoXyn3 and PfXynC in $p G A P Z \alpha A$ expression vector}

From PfXynC cDNA, a 591-bp DNA fragment was amplified by PCR with forward primer (PF1: 5'-CATTACTGTGAATTCCAATCAAT-

\footnotetext{
1 Abbreviations used: PoXyn3, Penicillium occitanis xylanase 3; PfXynC, Penicillium funiculosum xylanase C; GH11, glycoside hydrolase family 11; AOX1; alcohol oxidase 1
}

CACGACCAGCCAG-3') and reverse primer (PF2: 5'-CATTACTGTTCTAGACCGGACACTGTGATGGTACTA-3'). Similarly from PoXyn3 cDNA, a 483-bp DNA fragment was amplified by PCR with forward (PO1: 5'-CATTACTGTGAATTCATGAAACTGTTTCTGGCGGCG-3') and reverse (PO2: 5'-CATTACTGTTCTAGATTAGCTCGCCACAATGGTCG CGCT-3') primers. Primers include EcoRI sites (underlined) immediately upstream of the mature sequences (without signal peptides) and XbaI site downstream of the stop codon in the case of PfXynC. The EcoRI-XbaI digested PCR products were purified and inserted into the pGAPZ $\alpha$ A. P. pastoris expression vector, (pGAPZaA-PfXynC, 3691 bp; pGAPZaA-PoXyn3, 3583 bp) downstream of the GAP constitutive promoter as described by Sias [19]. Plasmid DNAs were isolated from $E$. coli cell cultures using the alkaline lysis procedure [20] and purified using the Wizard Plus Midipreps DNA Purification System (Promega). Restriction enzyme digestion and ligation steps with T4 DNA ligase were performed as recommended by the enzyme suppliers. Plasmid DNAs were introduced into $E$. coli $\mathrm{DH} 5 \alpha$ cells by electroporation using a gene pulser (Bio-Rad). The DNA nucleotide sequence was determined using the dideoxynucleotide chain termination method using an ABI PRISM 3100 Avant (Applied Biosystem) sequencer, according to the instructions of the manufacturer.

\section{Transformation of P. pastoris and selection of PoXyn3 and PfXynC-} best-producing transformants

Electrocompetent $P$. pastoris $\mathrm{X}-33$ cells were prepared using standard methods [21] and their transformation was performed by electroporation [20]. Prior to the yeast transformation, both recombinant plasmids were linearized by BglII. The recombinant yeast clones were selected on YPDS plates containing $100 \mu \mathrm{g} / \mathrm{ml}$ zeocin [20]. The colonies were subsequently screened by performing direct PCR on yeast colonies to confirm the correct integration of each PoXyn3 and PfXynC DNAs into the genome [20]. For the screening of the best-producing transformants, positive clones were grown in 250-ml Erlenmeyer flasks containing $50 \mathrm{ml}$ YPD medium with Zeocin, at $30^{\circ} \mathrm{C}$ for $30 \mathrm{~h}$ under shaking at $100 \mathrm{rpm}$. All yeast cultures had an initial optical density $(600 \mathrm{~nm})$ of 0.2 . After centrifugation $(10 \mathrm{~min}$ at $3000 \mathrm{~g})$, the culture supernatants were stored at $20^{\circ} \mathrm{C}$. The presence of recombinant xylanases in the culture supernatants was checked by performing SDS-PAGE. The three days time-course of recombinant xylanases secretion into the culture supernatant was determined using three transformants.

\section{Production of recombinant PoXyn 3 and PfXynC xylanases in P. pastoris}

A preculture with the best-producing transformants was performed for $24 \mathrm{~h}$ in a $250-\mathrm{ml}$ Erlenmeyer flask containing $50 \mathrm{ml}$ YPD medium. This culture was used to inoculate larger cultures at an optical density (600 nm) of 1, and grown in a 1-1 Erlenmeyer flask containing $200 \mathrm{ml}$ YPD medium at $30^{\circ} \mathrm{C}$ at $100 \mathrm{rpm}$. The cultures were stopped after $96 \mathrm{~h}$ and the cells were pelleted by centrifugation at $3000 \mathrm{~g}$ for $20 \mathrm{~min}$.

\section{Purification and characterization of recombinant PoXyn3 and PfXynC}

The recombinant PfXynC xylanase was purified from the culture supernatant after cultivation for $96 \mathrm{~h}$. Cell free medium was concentrated and interchanged with buffer A: $10 \mathrm{mM}$ Tris- $\mathrm{HCl}$ buffer ( $\mathrm{pH} 7.5$ ) by ultrafiltration through a $10-\mathrm{kDa}$ membrane (Millipore, USA). The total sample volume obtained $(10 \mathrm{ml})$ was then mixed with $5 \mathrm{ml}$ of the $\mathrm{Ni}_{2}$-nitrilotriacetate resin (Qiagen, CA, USA) equilibrated with Tris- $\mathrm{HCl}$ buffer (Buffer A). The mixture was loaded onto a chromatographic column and washed with $200 \mathrm{ml}$ of buffer 
Version définitive du manuscrit publiée dans / Final version of the manuscript published in:

Protein Expression and Purification (2013), Vol. 90, №.2, p. 195-201, DOl: 10.1016/j.pep.2013.06.007

Journal homepage: http://www.elsevier.com/locate/yprep

(A)

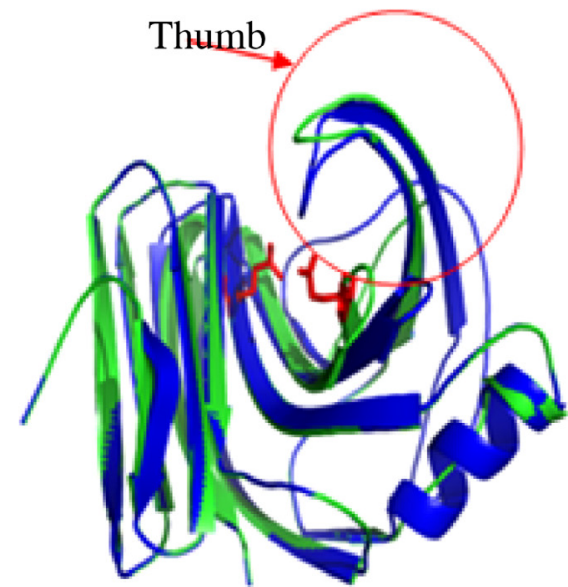

(b)

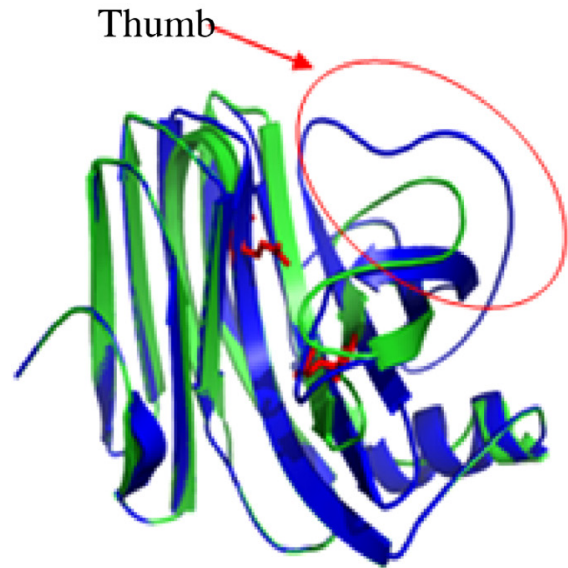

- Main-chain trace

Chain: A - [1 helice, 9 strands]

Chain: B- [1helice, 11 strands]

- Catalytic residues

2 Glutamates: E

(B)

Xyn3 de P.occitanis Pol6

XynC de P. funiculosum

Clustal Consensus
TYESGTNNGYYYTTWTNGGGEVTYTNGDNGEYSVTWVDCGDFTSGKGWNPANAQTVTYSG 60 TSOTGTNNGYYYSFWT-GGGEVTYTNGDNGEYSVTWVDCGDFTSGKGWNPANAOTVTYSG 59

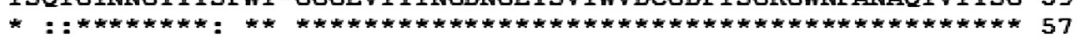

Xyn3 de P.occitanis Pol6

Xync de P. funiculosum

EFNPSGNAYLAVYGWTT--LVEFFLHLIWTYFWPGHHLP------------------AN 99

clustal Consensus EFNPSGNAYLAVYGWTTDPLVEYYILESYGTYNPSSGLTSLGOVTSDGGTYDIYSTORVN 119

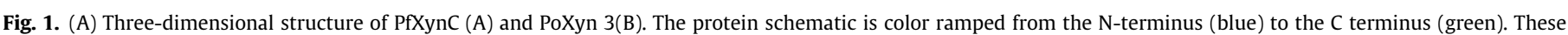

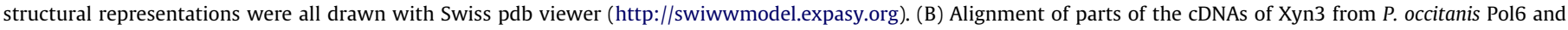
XynC from P. funiculosum around the sequence delimiting the thumb region. The dashes (-) indicate the naturally deleted region in the Xyn 3 sequence.

A. The recombinant PfXynC xylanase was eluted with a linear imidazole gradient from 0 to $500 \mathrm{mM}$ in buffer $\mathrm{A}$.

The recombinant PoXyn3 xylanase was purified by using an anion exchange chromatography on a PBE (Poly Buffer Exchanger) 94 column. The column was equilibrated and eluted in Tris- $\mathrm{HCl}$ $20 \mathrm{mM}, \mathrm{pH} 8 ; 20 \mathrm{mM} \mathrm{NaCl}$. The flow rate was $30 \mathrm{ml} / \mathrm{h}$, and the absorbance of the eluant was monitored at $280 \mathrm{~nm}$.

In both cases, the eluted fractions containing the recombinant proteins were pooled, concentrated and assayed for xylanase activity using the 3,5-dinitrosalicylic acid (DNS) assay (see below).

The presence of glycan chains in the purified xylanase was checked by the anthrone-sulfuric acid method using glucose as a standard [22].

To determine the optimal $\mathrm{pH}$ and temperature profiles, the enzymatic reaction was carried out at different $\mathrm{pHs}$ and temperatures. The effect of selected metal ions $(5 \mathrm{mM})$ on the activity of the purified enzyme was investigated by adding the divalent metal ions $\left(\mathrm{Ca}^{2+}, \mathrm{Co}^{2+}, \mathrm{Cu}^{2+}, \mathrm{Fe}^{2+}, \mathrm{Mg}^{2+}, \mathrm{Zn}^{2+}\right)$ to the reaction mixture. The effect of an enzyme inhibitor on xylanase activity was also studied using $5 \mathrm{mM}$ ethylenediaminetetraacetic acid (EDTA). Activity of the enzyme in the absence of metal ions or EDTA was used to define $100 \%$ activity under standard conditions. For the determination of apparent Michaelis-Menten constants, the initial velocities of the enzymes with increasing concentrations (0.1$10 \mathrm{mg} \mathrm{ml}^{-1}$ ) were measured at $30^{\circ} \mathrm{C}$ in Mcllvaine's buffer, $\mathrm{pH}$
5.5 , with substrate concentrations ranging from 2 to $20 \mathrm{mg} \mathrm{ml}^{-1}$. Due to the heterogeneous nature of polymeric substrates, their molar concentrations could not be calculated. Consequently, only an apparent value for the Michaelis constant, $\mathrm{K}_{\mathrm{m}}$ (app), was determined. The kinetic parameters were estimated using weighted nonlinear squares regression analysis with the Grafit software (Biosoft, Cambridge, UK).

\section{Xylanase activity and inhibition assays}

Both purified xylanases activities were measured using the DNS assay [23] as described in [6]. One unit of xylanase activity was defined as the amount of protein that released $1 \mu \mathrm{mol}$ of xylose $/ \mathrm{min}$ at $30^{\circ} \mathrm{C}$ and $\mathrm{pH} 5.5$.

Inhibition assays of the Penicillium xylanases were determined using low viscosity wheat arabinoxylan (LVAX) at $30^{\circ} \mathrm{C}$ and $\mathrm{pH}$ 5.5. Recombinant PfXynC and PoXyn3 were incubated with TAXII [24] up to an inhibitor/enzyme molar ratio of 30:1. All assays were carried out in triplicate.

\section{Purification of TAXI I}

TAXI-I (T. aestivum Xylanase Inhibitor Type I) was purified from wheat flour according to [24]. 
Version définitive du manuscrit publiée dans / Final version of the manuscript published in:

Protein Expression and Purification (2013), Vol. 90, №.2, p. 195-201, DOl: 10.1016/j.pep.2013.06.007

Journal homepage: http://www.elsevier.com/locate/yprep

198

\section{Results and discussion}

Expression and purification of PfXynC and PoXyn3 xylanases in P. pastoris

In this report, we expressed and characterized two family GH11 xylanases from Penicillium species. Both $P$. occitanis and $P$. funiculosum xylanases were efficiently produced in $P$. pastoris X33. In fact, the $672 \mathrm{bp}$ and $483 \mathrm{bp}$ cDNAs coding for PfXynC and PoXyn3 xylanases were amplified by PCR and fused in-frame to the $\alpha$-factor secretion signal of the pGAPZ $\alpha$ A expression vector and the GAP promoter-driven constitutive expressions of these two proteins were achieved by integrating linearised pGAPZ $\alpha A-P o X y n 3$ and pGAPZaA-PfXynC plasmids into the X-33 wild type P. pastoris genome at the GAP locus. The presence of xylanases inserts in these Zeo-resistant transformants was checked by PCR. Eighteen positive clones were randomly chosen for both xylanases cultures. One of the two clones was introduced into $P$. pastoris X33. The transformants were screened on YEPD plate containing $0.1 \mathrm{mg} / \mathrm{ml}$ Zeocin and further confirmed by PCR using $5^{\prime}$ - and 3'-AOX primers.

Purification of the recombinant PfXynC was facilitated by the presence of six His residues at the N-terminus of the enzyme, allowing purification of the xylanase using a one-step Ni-NTA affinity chromatography. PoXyn3 did not contain an His-tag and was readily purified by anion exchange chromatography. Both enzymes were purified to homogeneity with purification yields of $49 \%$ and $43 \%$ and a purification yield of 2.17 and 1.14-fold for PoXyn3 and PfXynC, respectively (Table 1). SDS-PAGE analysis of the purified enzymes showed the presence of one band corresponding to an apparent molecular mass of about 30 and $20 \mathrm{kDa}$ for PfXynC and PoXyn3, respectively (Fig. 2).

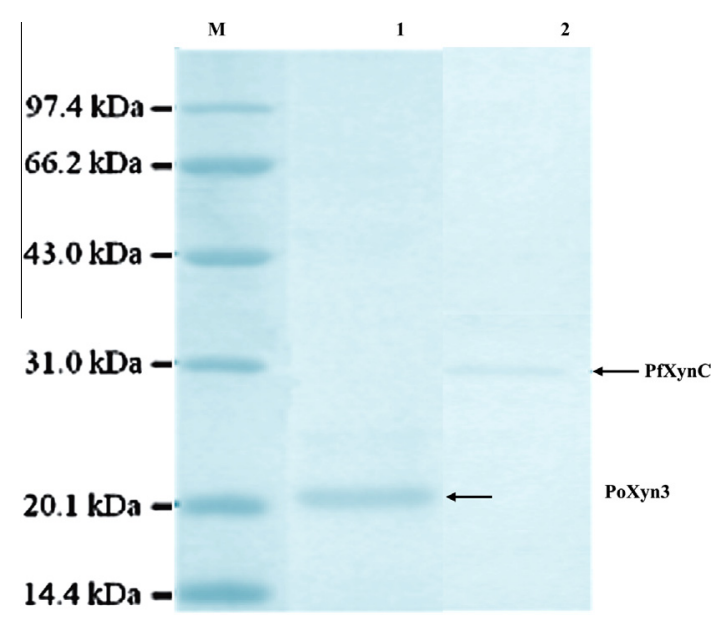

Fig. 2. SDS-PAGE of recombinant PfXynC and PoXyn3 secreted by P. pastoris. Lane M: protein marker (Fermentas). Lane 1: $15 \mu$ l of purified culture supernatant of PoXyn3; lane 2: $10 \mu \mathrm{l}$ of purified mature PfXynC. The protein gels were stained with Coomassie brilliant blue G250.
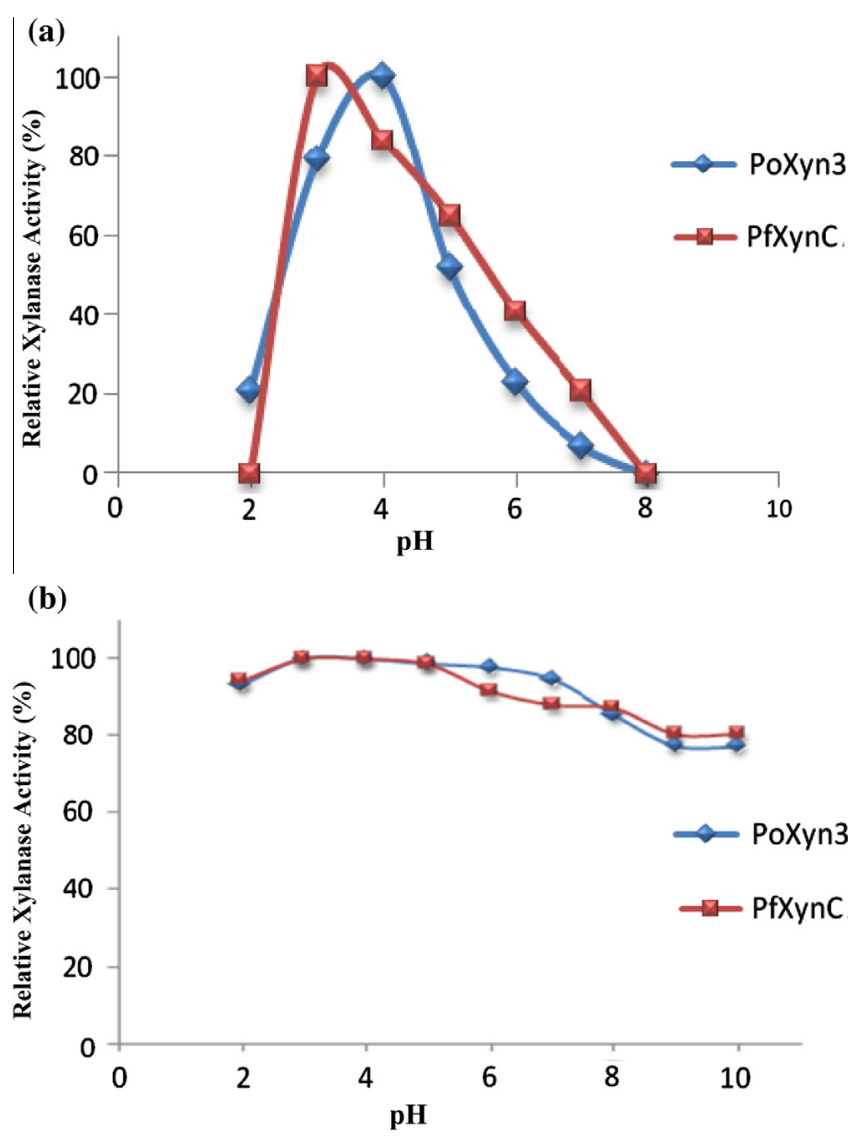

Fig. 3. Effect of $\mathrm{pH}$ on (a) activity and (b) stability of the purified xylanases PoXyn3 and PfXynC. The xylanase activity was assayed in the $\mathrm{pH}$ range $2-10$ using buffers at different $\mathrm{pH}$ values at $45^{\circ} \mathrm{C}$ and $40^{\circ} \mathrm{C}$ for PoXyn 3 and PfXynC, respectively. The maximum activity obtained at $\mathrm{pH} 3.0$ was taken as $100 \%$. The $\mathrm{pH}$ stability was determined by incubating the enzymes in different buffers at $4{ }^{\circ} \mathrm{C}$ for $24 \mathrm{~h}$ and the residual activity was measured at optimum $\mathrm{pH}$ and temperatures for both xylanases. The activity of the enzyme before incubation was taken as $100 \%$.

\section{Biochemical characterization of recombinant xylanases}

The N-terminal sequences of PoXyn3 and PfXynC (T-Y-E-S-G-T$\mathrm{N}$ and T-S-D- I-T-Q-N, respectively) were identical to the corresponding deduced amino acid sequences, indicating a correct cleavage of the $\alpha$-factor by the Kex2. The extent of glycosylation of the recombinant xylanases was determined by the anthrone method. PoXyn 3 showed a $17.7 \%$ glycosylation of compared to $10.8 \%$ for the native one whereas PfXynC glycosylation was slightly higher than the expressed one in E. coli (which were not glycosilated) [18].

The optimal temperature of the purified xylanases was determined at $\mathrm{pH} 3.0$ and 4.0 for 60 min for PoXyn3 and PfXynC, respectively at different temperatures $\left(30-80^{\circ} \mathrm{C}\right)$. The purified enzymes showed optimal temperatures at 40 and $45^{\circ} \mathrm{C}$ for PoXyn3 and PfXynC, respectively (Fig. 4a). To determine the optimal pH, PfXynC and PoXyn3 were incubated at their optimum temperatures for 10 min at different pHs (2-10), showing an optimal $\mathrm{pH}$ of 3.0

Table 1

Purification of recombinant xylanases PoXyn3 and PfXynC from $P$. pastoris.

\begin{tabular}{|c|c|c|c|c|c|c|}
\hline Xylanases & Purification step & Total activity (UT) & Total protein (mg) & Specific activity (UI/mg) & Recovery (\%) & Purification (x-fold) \\
\hline \multirow[t]{2}{*}{ PoXyn3 } & Crude extract & 2823 & 173.4 & 16.28 & 100 & 1 \\
\hline & PBE-94 & 1380 & 39 & 35.38 & 48.88 & 2.17 \\
\hline \multirow[t]{2}{*}{ PfXynC } & Crude extract & 4443 & 19.2 & 231.4 & 100 & 1 \\
\hline & His-Trap & 1918.5 & 7.23 & 265.35 & 43.18 & 1.14 \\
\hline
\end{tabular}


Version définitive du manuscrit publiée dans / Final version of the manuscript published in:

Protein Expression and Purification (2013), Vol. 90, N.2, p. 195-201, DOI: 10.1016/j.pep.2013.06.007

Journal homepage: http://www.elsevier.com/locate/yprep

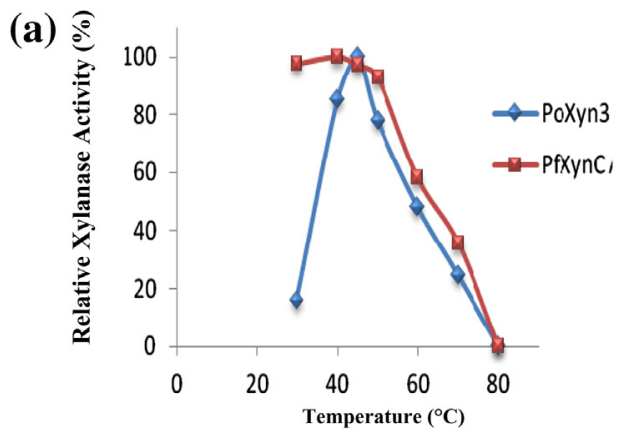

(b)

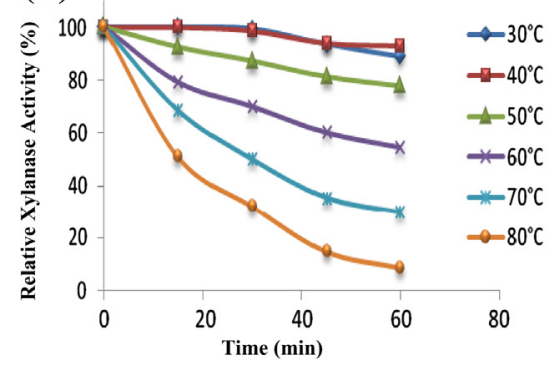

(c)

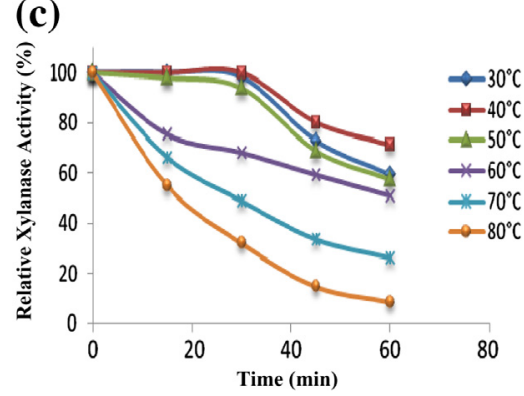

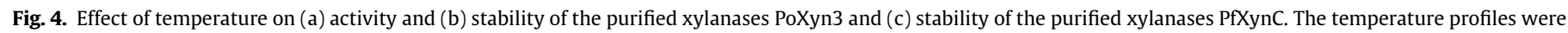

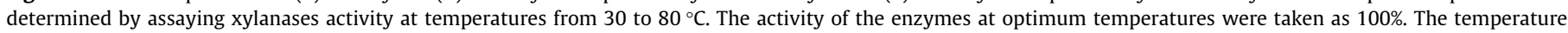

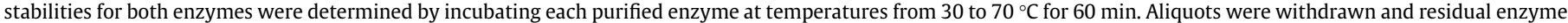
activities were measured under standard assay conditions. The non-heated enzyme was taken as $100 \%$.

and 4.0, respectively (Fig. 4a). Furthermore, the purified enzymes were highly stable within a broad $\mathrm{pH}$ range. The enzymes retained $100 \%$ of their activity over a wide $\mathrm{pH}$ range from 2.0 to 10.0 (Fig. 3b).

The purified PoXyn3 enzyme was stable at temperatures below $30{ }^{\circ} \mathrm{C}$. The enzyme retained about $70 \%$, its initial activity after $60 \mathrm{~min}$ incubation at $60{ }^{\circ} \mathrm{C}$ (Fig. 4b). The PfXynC enzyme displayed almost the same profile across increasing temperatures, retaining more than $80 \%$ of its initial activity after 60 min incubation at $50{ }^{\circ} \mathrm{C}$ suggesting that these xylanases are mesophilic enzymes.

The effect of selected bivalent metal ions on the recombinant xylanases was investigated. Under optimum conditions deter-

Table 2

Effect of metal ions ( $5 \mathrm{mM}$ ) on the activity of the xylanases PoXyn3 and PfXynC.

\begin{tabular}{lcc}
\hline Treatment & $\begin{array}{c}\text { Relative PoXyn3 } \\
\text { activity (\%) }\end{array}$ & $\begin{array}{l}\text { Relative PfXynC } \\
\text { activity (\%) }\end{array}$ \\
\hline None metal ions (5 mM) & 100 & 100 \\
EDTA & 94.57 & 94.09 \\
$\mathrm{Ca}^{2+}$ & 89.34 & 95.26 \\
$\mathrm{Co}^{2+}$ & 105.19 & 101.29 \\
$\mathrm{Cu}^{2+}$ & 105.12 & 105.12 \\
$\mathrm{Fe}^{2+}$ & 107.63 & 106.64 \\
$\mathrm{Mg}^{2+}$ & 93.15 & 91.24 \\
$\mathrm{Zn}^{2+}$ & 105.83 & 103.28 \\
\hline
\end{tabular}

mined above, a slight activity enhancement of $105-107 \%$ and of $101-106 \%$ for PoXyn3 and PfXynC, respectively, in the presence of $5 \mathrm{mM} \mathrm{Co}{ }^{2+}, \mathrm{Cu}^{2+}, \mathrm{Fe}^{2+}$ and $\mathrm{Zn}^{2+}$ metal ions was observed (Table 2). However, in the presence of $5 \mathrm{mM} \mathrm{Ca}^{2+}$ and $\mathrm{Mg}^{2+}$ metal ions, the enzymes activities were reduced to $89 \%$ and $93 \%$ for PoXyn3, respectively, and to $95 \%$ and $91 \%$ for PfXynC, respectively from their initial activity. Preincubation of the enzyme with a $5 \mathrm{mM}$ EDTA did not affect the activities; the enzymes recovered their original activities following addition of any of the bivalent metal ions.

Overall, PoXyn3 and PfXynC recombinant xylanases were respectively similar to native PoXyn3 and to PfXynC expressed in E. coli in terms of molecular mass, $\mathrm{pH}$, and temperature optimum and specific activity [14,18].

\section{Kinetic parameters, substrate and inhibition specificity}

Although PfXynC and PoXyn3 share 89.3\% amino acid homology, the 3D modeling of the two xylanases revealed critical differences in the thumb region (Fig. 1B) [10], the two enzymes showed different enzymatic and inhibition profiles. PoXyn3 showed a fivefold decrease in catalytic turnover compared to PfXynC, but likely the PoXyn3 remained active despite of its deleted thumb. In fact, the kinetics parameters of PfXynC and PoXyn3 xylanases were determined using oat spelt xylan, wheat arabinoxylan (LVAX, Low Viscosity ArabinoXylan) and birchwood xylan. PfXynC showed

Table 3

Kinetic parameters of purified recombinant xylanases PoXyn3 and PfXynC in different substrates.

\begin{tabular}{|c|c|c|c|c|c|}
\hline Substrate & Enzyme & $V_{m}(U / m g)$ & $K_{\mathrm{m}}(\mathrm{mg} / \mathrm{ml})$ & $K\left(\sec ^{-1}\right)$ & $\mathrm{K}_{\mathrm{t}} / \mathrm{K}_{\mathrm{m}}\left(\mathrm{mlsec}^{-1} \mathrm{mg}^{-1}\right)$ \\
\hline \multirow[t]{2}{*}{ Oat spelt xylan (1\%) } & PoXyn3 & $806.3 \pm 0.9$ & $14.13 \pm 0.4$ & 629.689 & 44.53 \\
\hline & PfXynC & $2540 \pm 140$ & $14.08 \pm 0.7$ & 1231 & 87.42 \\
\hline \multirow[t]{2}{*}{$\operatorname{LVAX}(1 \%)$} & PoXyn3 & $902.7 \pm 0.7$ & $14.54 \pm 0.1$ & 715.658 & 49.42 \\
\hline & PfXynC & $8559+0.1$ & $14.4+0.7$ & 2939 & 204 \\
\hline \multirow[t]{2}{*}{ Birchwood (1\%) } & PoXyn3 & $784.4 \pm 0,5$ & $14.01 \pm 0.1$ & 594.360 & 42.42 \\
\hline & PfXynC & $2729 \pm 0.4$ & $14.08 \pm 0.2$ & 3024.14 & 214.78 \\
\hline
\end{tabular}


Version définitive du manuscrit publiée dans / Final version of the manuscript published in:

Protein Expression and Purification (2013), Vol. 90, N.2, p. 195-201, DOI: 10.1016/j.pep.2013.06.007 Journal homepage: http://www.elsevier.com/locate/yprep

200

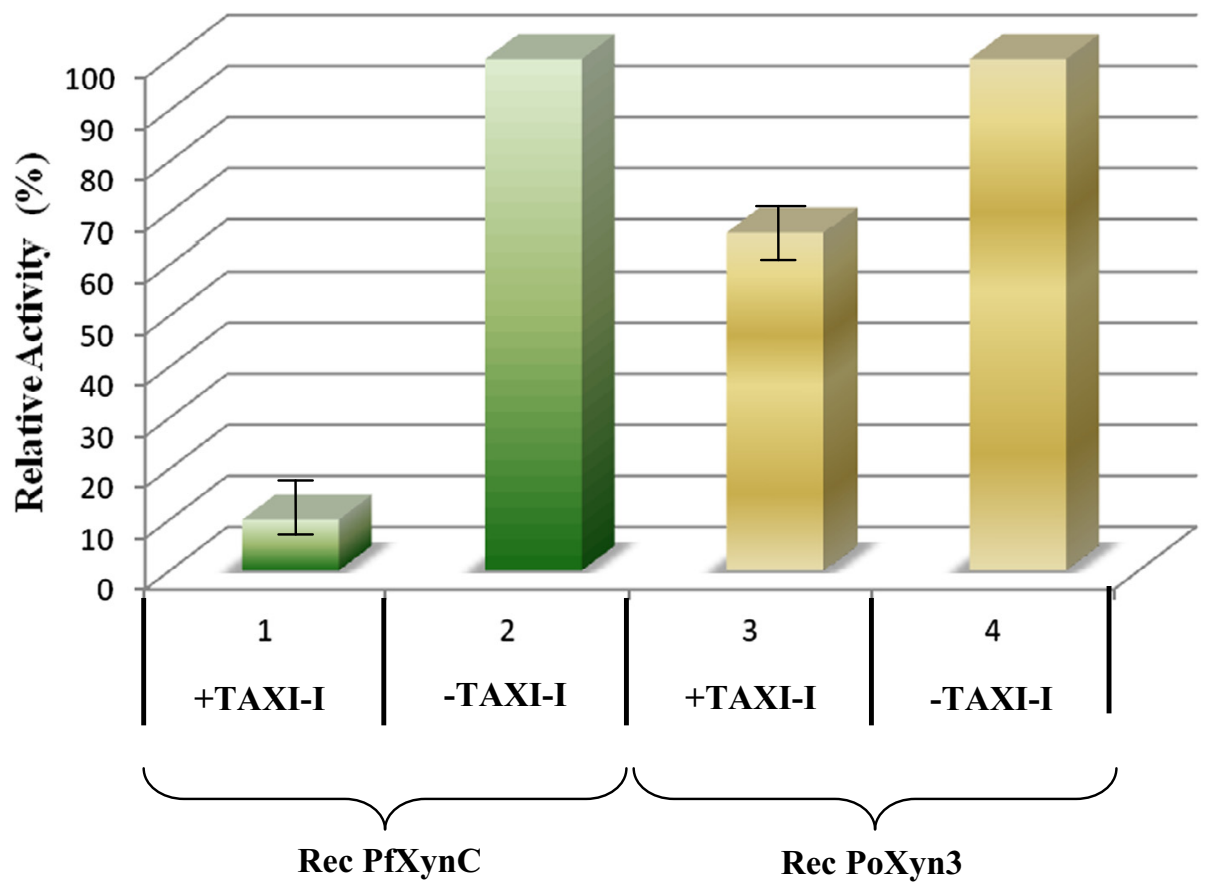

Fig. 5. Inhibition profile of PfXynC and PoXyn3 by TAXI-I. Values represent mean \pm SE of three independent experiments.

Table 4

Inhibition Kinetic of PoXyn3 and PfXynC toward TAXI-I inhibitor used at 50nM.

\begin{tabular}{|c|c|c|c|c|}
\hline & \multicolumn{2}{|l|}{ Poxyn 3} & \multicolumn{2}{|l|}{ PfXync } \\
\hline & {$[$ TAXI-I $]=0 \mathrm{nM}$} & {$[$ ТАХІ-I $]=100 \mathrm{nM}$} & {$[$ TAXI-I $]=0 \mathrm{nM}$} & {$[$ TAXI-I $]=100 \mathrm{nM}$} \\
\hline $\operatorname{Vmax}(\mu \mathrm{mole} / \mathrm{min})$ & 28.57 & $28.57 \pm 0.34$ & 9.80 & $9.80 \pm 1.32$ \\
\hline $\mathrm{Km}^{\mathrm{app}}(\mathrm{mg} / \mathrm{ml})$ & 10 & - & 4,34 & - \\
\hline $\mathrm{Km}^{\text {app }}(\mathrm{mg} / \mathrm{ml})$ & - & $166.6 \pm 0.12$ & - & $89,2 \pm 0.09$ \\
\hline
\end{tabular}

the highest catalytic efficiency on LVAX with a $\mathrm{k}_{\text {cat }} / \mathrm{K}_{\mathrm{m}}$ of $204 \mathrm{~s}^{-1}$ (Table 3) while PfXynC hydrolysed LVAX at a higher rate but with a lower apparent affinity compared to PoXyn3 (Table 2). The $\mathrm{k}_{\mathrm{cat}}$ was almost five times higher in the case of PfXynC than the ones of PoXyn3 irrespective of the nature of the substrate, whereas the apparent affinity was similar between the two recombinant xylanases. The PfXynC expressed in E. coli [18] showed similar kinetic parameters, which confirms that post-translational modifications in $P$. pastoris did not affect folding and/or activity of the recombinant protein.

The ability of the proteinaceous wheat inhibitor, TAXI-I, to inhibit PoXyn3 and PfXynC was further evaluated. Using LVAX as substrate, no decrease in xylanase activity was observed up to a TAXI-I/PoXyn3 ratio of 30:1 (Fig. 5) (Table 4) for PoXyn3 whereas PfXynC was strongly inhibited. In fact, PfXynC overexpressed in $P$. funiculosum has been shown to efficiently degrade birchwood xylan and soluble wheat arabinoxylans and its activity was strongly inhibited by three xylanase inhibitor proteins from wheat; XIP-I, TAXI I and TAXI II [17] suggesting that post-translational modifications in Pichia do not affect its inhibition sensitivity. Similar results were obtained with XynA, especially with the XIP inhibitor, from Penicillium griseofulvum [18]. Although TAXI-I typically inhibits fungal and bacterial xylanases, the inability of TAXI-I to inhibit $P$. occitanis xylanase can be explained by the structural determinants of inhibitor specificity, in particular, around the "thumb" region of the enzyme, a key determinant of the xylanase-inhibitor interaction $[25,26]$. The lack of twenty amino acids in the thumb of the PoXyn3 [14] would cause this short loop to adopt a strikingly different conformation that would introduce steric clashes with TAXI-I, thus, preventing inhibitor binding. This result stresses the importance of the tip region located immediately after the conserved Gly (Fig. 1B)[25]. In fact, the structure of the TAXI-I-A. niger xylanase complex (1T6G.pdb) reveals a direct interaction of the inhibitor with the active site region of the enzyme and further substrate-mimicking contacts with binding subsites filling the whole substrate-docking region [27].

Since PoXyn3 is a fungal xylanase that belongs to the GH11 family, it may be the target of other plant xylanase inhibitors such as XIP-I and TAXI-II [6]. We can predict that the absence of key aminoacids within the thumb region of PoXyn3 may affect binding to XIP-I $[25,26]$. From an enzymological point of view, PoXyn3 thus represent an attractive model to study structure-function relationships in the GH11 xylanase family. These reported differences in the action pattern of Penicillium xylanases on arabinoxylan, together with their distinct sensitivity towards TAXI-I, are to be taken into consideration for specific food processing applications.

\section{Acknowledgments}

We express our gratitude to Prof. Gérard Tiraby and Dr. Henry Durand (Cayla Company, France) for kindly supplying the Penicillium occitanis (Pol6) strain used in this work. We are also grateful to Prof. Radhouane Ellouz for his stimulating and beneficial discussion. We also thank Dr. Mohamed Eljawa (CBS) for the DNA sequencing. This work was supported financially by the "Ministère de l'Enseignement Supérieur, de la Recherche Scientifique et de la 
Version définitive du manuscrit publiée dans / Final version of the manuscript published in:

Protein Expression and Purification (2013), Vol. 90, №.2, p. 195-201, DOI: 10.1016/j.pep.2013.06.007

Journal homepage: http://www.elsevier.com/locate/yprep

Technologie-Tunisia" through a grant to "Unité Enzyme et Bioconversion - ENIS".

\section{References}

[1] P. Biely, Enzymological aspects of the production of microbial hemicellulases in: Coughlan MP, Hazlewood GP (eds) Hemicellulose and hemicellulases. Portland, London, 1993, pp. 29-51.

[2] P.M. Coutinho, B. Henrissat, Carbohydrate-active enzymes: an integrated database approach, in: H.J. Gilbert, G. Davies, B. Henrissat, B. Svensson (Eds.), Recent Advances in Carbohydrate Bioengineering, The Royal Society of Chemistry, Cambridge, UK, 1999, pp. 3-12.

[3] G. Paës, J.G. Berrin, J. Beaugrand, GH11 xylanases: structure/function/ properties relationships and applications, Biotechnol. Adv. 30 (3) (2012) 564-592.

[4] T. Collins, C. Gerday, G. Feller, Xylanases, xylanase families and extremophilic xylanases, FEMS Microbiol. 29 (2005) 3-23.

[5] C.M. Courtin, A. Roelants, J.A. Delcour, Fractionation-reconstitution experiments provide insight into the role of endoxylanases in bread-making, J. Agric. Food Chem. 47 (1999) 1870-1877.

[6] J.G. Berrin, N. Juge, Factors affecting xylanase functionality in the degradation of arabinoxylans, Biotechnol. Lett. 30 (7) (2008) 1139-1150.

[7] A. Törrönen, J. Rovinen, Structural and functional role of low molecular weight endo-1,4- $\beta$-xylanases, J. Biotechnol. 57 (1997) 137-149.

[8] T.A. Tahir, J.G. Berrin, R. Flatman, A. Roussel, P. Roepstorff, G. Williamson, N. Juge, The Dual nature of the wheat xylanase protein inhibitor XIP-I structural basis for the inhibition of family 10 family 11 xylanases, J. Biol. Chem. 277 (2002) 44035-44043.

[9] N. Juge, J.A. Delcour, Xylanase inhibitors: structure, function and evolution, Curr. Enzyme Inhib. 2 (2006) 29-35.

[10] G. Gellissen, Heterologous protein production in methylotrophic yeasts, Appl. Microbiol. Biotechnol. 54 (2000) 741-750.

[11] Y. Yang, M.E. Lowe, Human pancreatic triglyceride lipase expressed in yeast cells: purification and characterization, Protein Expr. Purif. 13 (1998) 36-40.

[12] H.R. Waterham, M.E. Digan, P.J. Koutz, S.V. Lair, J.M. Cregg, Isolation of the Pichia pastoris glyceraldehyde-3-phosphate dehydrogenase gene and regulation and use of its promoter, Gene 186 (1997) 37-44.

[13] M. Vardakou, C.W. Dumon, J. Murray, P. Christakopoulos, P.D. Weiner, N. Juge J.R. Lewis, J.H. Gilbert, E.J. Flint, Understanding the structural basis for substrate and inhibitor recognition in eukaryotic GH11 xylanases, J. Mol. Biol. 375 (2008) 1293-1305.

[14] D. Driss, F. Bhiri, L. Elleuch, N. Bouly, I. Stals, N. Miled, M. Blibech, R. Ghorbel, S.E. Chaabouni, Purification and properties of an extracellular acidophilic endo-1,4- $\beta$-xylanase, naturally deleted in the "thumb", from Penicillium occitanis Pol6, J. Process Biochem. 46 (2011) 1299-1306.

[15] D. Driss, B. Fatma, S. Mariem, B. Souhail, S.E. Chaabouni and R. Ghorbel, Purification and Properties of a Thermostable Xylanase GH 11 from Penicillium occitanis Pol6. J. Applied Biochem. Biotechnol. DOI 10.1007/s12010-012-98243, 2012.

[16] D. Driss, F. Bhiri, R. Ghorbel, S.E. Chaabouni, Cloning and constitutive expression of His-tagged xylanase GH 11 from Penicillium occitanis Pol6 in Pichia pastoris X33: purification and characterization, J. Protein Expr. Purif. 83 (2012) 8-14.

[17] C.S. Furniss, N.J. Belshaw, M.J. Alcocer, G. Williamson, G.O. Elliott, K. Gebruers, N.P. Haigh, N.M. Fish, P.A. Kroon, A family 11 xylanase from Penicillium funiculosum is strongly inhibited by three wheat xylanase inhibitors, Biochim. Biophys. Acta 1598 (2002) 24-29.

[18] J.G. Berrin, E.H. Ajandouz, J. Georis, F. Arnaut, N. Juge, Substrate and product hydrolysis specificity in family 11 glycoside hydrolases: an analysis of Penicillium funiculosum and Penicillium griseofulvum xylanases., Appl Microbiol Biotechnol 74 (2007) 1001-1010.

[19] B. Sias, F. Ferrato, P. Grandval, D. Lafont, P. Boullanger, A. De Caro, B. Leboeuf, R. Verger, F. Carriere, Human pancreatic lipase-related protein 2 is a galactolipase, Biochemistry 43 (2004) 10138-10148.

[20] J. Sambrook, E.F. Fritsch, T. Maniatis, Molecular Cloning: A Laboratoty Manual, Cold Spring Harbor Laboratory Press, New York, 1989.

[21] J.D. Bendtsen, H. Nielsen, G.V. Heijne, S. Brunak, Improved prediction of signal peptides-SignalP 3.0, J. Mol. Biol. 340 (2004) 783-795.

[22] R. Spiro, Analysis of sugar found in glycoproteins, Methods Enzymol. 256 (1966) 3-26.

[23] G.L. Miller, Use of dinitrosalicylic acid reagent for the determination of reducing sugars, Anal. Chem. 31 (1959) 426-428.

[24] W. Debyser, W.J. Peumans, E.J.M. Van Damme, J.A. Delcour, Triticum aestivum xylanase inhibitor (TAXI), a new class of enzyme inhibitor effecting breadmaking performance, J. Cereal Sci. 30 (1999) 39-43.

[25] T.A. Tahir, J.G. Berrin, R. Flatman, A. Roussel, P. Roepstorff, G. Williamson, N. Juge, Specific characterization of substrate and inhibitor binding sites of a glycosyl hydrolase family 11 xylanase from Aspergillus niger, J. Biol. Chem. 277 (2002) 44035-44043.

[26] F. Payan, P. Leone, S. Porciero, C. Furniss, T.A. Tahir, G. Williamson, A. Durand, P. Manzanares, H.J. Gilbert, N. Juge, A. Roussel, The dual nature of the wheat xylanase protein inhibitor XIP-I: structural basis for the inhibition of family 10 and family 11 xylanases, J. Biol. Chem. 279 (2004) 36029-36037.

[27] S. Sansen, C.J. De Ranter, K. Gebruers, K. Brijs, C.M. Courtin, J.A. Delcour, A. Rabijns, Structural basis for inhibition of Aspergillus niger xylanase by Triticum aestivum xylanase inhibitor-I, J. Biol. Chem. 279 (2004) 36022-36028. 